Distribución y densidad del conejo zacatuche (Romerolagus diazi) en el Área Natural Protegida Corredor Biológico Chichinautzin

\title{
Distribution and density of the zacatuche rabbit (Romerolagus diazi) at the Protected Natural Area "Corredor Biológico Chichinautzin"
}

\author{
Areli Rizo-Aguilar ${ }^{1}$, Christian Delfín-Alfonso², Alberto González-Romero ${ }^{3}$ y José Antonio Guerrero ${ }^{*}$
}

\footnotetext{
${ }^{1}$ Facultad de Ciencias Biológicas, Universidad Autónoma del Estado de Morelos. Av. Universidad 1001, 62209. Cuernavaca, Morelos, México. Email: areli.rizo@uaem.mx (ARA), aguerrero@uaem.mx (JAG).

${ }^{2}$ Instituto de Investigaciones Biológicas, Universidad Veracruzana. Av. Luis Castelazo Ayala s/n, 91190. Xalapa, Veracruz, México Email: cada7305@gmail.com (CDA).

${ }^{3}$ Instituto de Ecología, A. C. Carretera antigüa a Coatepec № 351, El Haya, 91070. Xalapa, Veracruz, México. Email: alberto. gonzalez@inecol.mx (AGR).

${ }^{*}$ Corresponding author
}

The Protected Natural Area (PNA) "Corredor Biológico Chichinautzin" contains a large area of bunchgrasses, a habitat that is necessary for the zacatuche rabbit to survive. As part of a monitoring program used to evaluate the status of the zacatuche rabbit's populations within this PNA, we estimated its distribution by using direct (sightings) and indirect methods (latrines) during visits performed to all the available habitats. Additionally, we estimated the annual density of the zacatuche rabbit using a line transect method, sampling eight, one-kilometer-long transects monthly during one year. Based on 101 latrine records and 48 sightings, a distribution map was prepared for the region using the convex polygon method in ArcView. Most of this distribution $\left(166.43 \mathrm{~km}^{2}\right)$ represents an area that had not been previously reported in the literature for the zacatuche rabbit. Using the half-normal model that best fit the data, we estimated a density of 4.2 rabbits/ha. Our results suggest that the Corredor Biológico Chichinautzin meets the criteria necessary to be cataloged as a core distribution area for the zacatuche rabbit. Therefore, we suggest that both management and conservation of this habitat within the PNA should be made a priority.

El Área Natural Protegida (ANP) “Corredor Biológico Chichinautzin” contiene una extensa área de pastizales amacollados, un hábitat que es necesario para que el zacatuche sobreviva. Como parte de un programa de monitoreo para evaluar el estado de las poblaciones del conejo zacatuche en esta ANP, estimamos su distribución utilizando métodos directos (avistamientos) e indirectos (letrinas) durante visitas a todos los hábitats disponibles. Además, se estimó su densidad anual utilizando el método de transectos lineales, muestreando cada mes ocho transectos de un km de largo durante un año. Con base en los registros de 101 letrinas y 48 avistamientos, se elaboró un mapa de distribución para la región mediante el método del polígono convexo en ArcView. La mayor parte de esta distribución $(166,43$ km²) representa un área que no habían sido previamente reportada en la literatura para el zacatuche. Usando el modelo half-normal que fue el mejor que se ajustó a los datos, se estimó una densidad de 4.2 conejos/ha. Nuestros resultados sugieren que el Corredor Biológico Chichinautzin cumple con los criterios necesarios para ser catalogado como un área núcleo de distribución para el zacatuche. Por lo tanto, sugerimos que el manejo y la conservación de este hábitat en el ANP deben ser una prioridad.

Key words: conservation, density, distribution, IUCN Romerolagus diazi.

๑) 2016 Asociación Mexicana de Mastozoología, www.mastozoologiamexicana.org 


\section{Introduction}

The zacatuche rabbit (Romerolagus diazi) is an endemic species to the Trans-Mexican Volcanic Belt. Previous studies have indicated that the zacatuche rabbit has a strong preference for subalpine habitats $(2,800-4,200 \mathrm{~m})$, with higher abundances found in open pine forests (Pinus spp.) that have abundant bunch grasses (Festuca tolucensis, Muhlenbergia spp., Jarava ichu) in their understory (Velázquez and Heil 1996; Rizo-Aguilar et al. 2015). Based on this, the zacatuche rabbit is considered a habitat specialist. Its habitat has been severely fragmented due to factors such as urbanization, agricultural conversion, illegal logging, and wildfires (Velázquez et al. 2011). As a result, the species is classified as endangered on the IUCN Red List (AMCELA et al. 2008), and as at risk of extinction by Mexican Legislation (SEMARNAT 2010).

Until the late 1980s the precise area of distribution of $R$. diazi was unknown. López-Forment and Cervantes (1979) estimated that its area covered a total of $150 \mathrm{~km}^{2}$. In contrast, Hoth et al. (1987) only found zacatuche rabbits in three isolated areas in the central Trans-Mexican Volcanic Belt: the Sierra Nevada mountains, and the Tlaloc and Pelado volcanoes. The total area of distribution estimated by Hoth et al. (1987) was $280 \mathrm{~km}^{2}$. Motivated by these contrasting findings, Velázquez et al. (1996) conducted a survey throughout the proposed geographic range of $R$. diazi to document its historical and current distribution. Based on collection records, sightings, traces (pellets) and interviews with farmers, they estimated a distribution area of $386 \mathrm{~km}^{2}$. Within this, four core and 12 peripheral areas were recognized. This information was used to do the distributions maps for the zacatuche rabbit that are now available in the literature and on web pages (Velázquez et al. 1996; AMCELA et al. 2008).

Studies conducted on the Pelado Volcano, one of the four core areas of zacatuche rabbit, indicated that densities estimated using line transects ranged from 0.11 to 1.20 rabbits/ha according to habitat characteristics (Velázquez 1994). Other studies conducted on the Pelado, Tláloc and Iztaccíhuatl Volcanoes based on fecal pellet counts have shown that the abundance of this species is highly variable, ranging from 0.1 to 3.1 latrines $/ \mathrm{m}^{2}$ (Velázquez 1994; Velázquez and Heil 1996; Velázquez et al. 1996).

The Corredor Biológico Chichinautzin (hereafter $\mathrm{COBIOCH}$ ) is a Protected Area located in the northern part of the state of Morelos (Figure 1). The area of the $\mathrm{COBIOCH}\left(657.2 \mathrm{~km}^{2}\right)$ includes Fractions I and II, covering the zone between Lagunas de Zempoala and El Tepozteco National Parks, and creating a biological corridor that ensures the continuity of ecological processes of the biota in the area. It contains on of the largest areas of grassland in centra Mexico (CabreraGarcía et al. 2006), and likely acts as a corridor connecting the zacatuche rabbit populations of two core areas of its distribution, the Tláloc Volcano with those of the Pelado Volcano (Velázquez et al. 1996). Paradoxically, very little is known about the current status of Romerolagus diazi in the area, and there are only a few historical records dating from Velázquez et al. (1996).

In this paper we provide evidence of newly occupied areas by $R$. diazi as well as its annual density within the $\mathrm{COBIOCH}$ and its influence area. The outcomes are further discussed in the light of the relevance of this protected area for conservation of the endangered zacatuche rabbit.

\section{Material and Methods}

To document the distribution of the zacatuche rabbit, from June to November 2008, and from June to December 2011 we randomly selected 173 points (Appendix 1) from all habitats with bunchgrasses in the $\mathrm{COBIOCH}$. Each point consisted of an area of $50 \times 50 \mathrm{~m}$ within which exhaustive searches were conducted and latrines counted by at least 4 people. The zacatuche faeces are reliably distinguished from the ones of the other two lagomorphs Sylvilagus floridanus 
and S. cunicularius due to their size and shape (Hoth et al. 1987). The latrine counting method has been used previously to document the abundance and distribution of the zacatuche rabbit (Fa et al. 1992; Velázquez 1994). In addition, we recorded all zacatuches sighted along the roads and in the grasslands while driving or walking between sampling sites. Each sampling point and rabbit sighting was recorded using the Universal Transverse Mercator (UTM) geographic coordinate system, and was uploaded to a Geographical Positioning System software using a Garmin GPS device (coordinate output to WGS84). With these records, we estimated the area of distribution for the species within the $\mathrm{COBIOCH}$, and we compared it to the distribution area estimated using all of the records reported by Velázquez et al. (1996). In both cases, we first generated a buffer area of $100 \mathrm{~m}$ in radius around the location of each record, to determine the area where the species might be located. We then estimated its probable distribution area using the Minimum Convex Polygon method, and the Fixed Kernel Isopleths method, both at a $95 \%$ confidence level (Harris et al. 1990; Worton 1995). The output models for each method were combined spatially (MCP + Kernel model), and were subsequently cut with contours above 2,800 m, the lower elevation limit recorded for the area; finally we intersected it with the polygon of the $\mathrm{COBIOCH}$ to measure the area that lies within the protected natural area. The process was performed using the "Animal Movement Analyst" for ArcView 3.2.

The annual density of the zacatuche rabbit was estimated using the line transect method (Buckland et al. 1993). For this, eight reasonably straight, permanent 1000-m-long walking line transects were established, at least $1 \mathrm{~km}$ apart, to cover different habitats. Monthly zacatuche rabbit surveys were conducted from March 2010 to February 2011. Two experienced observers

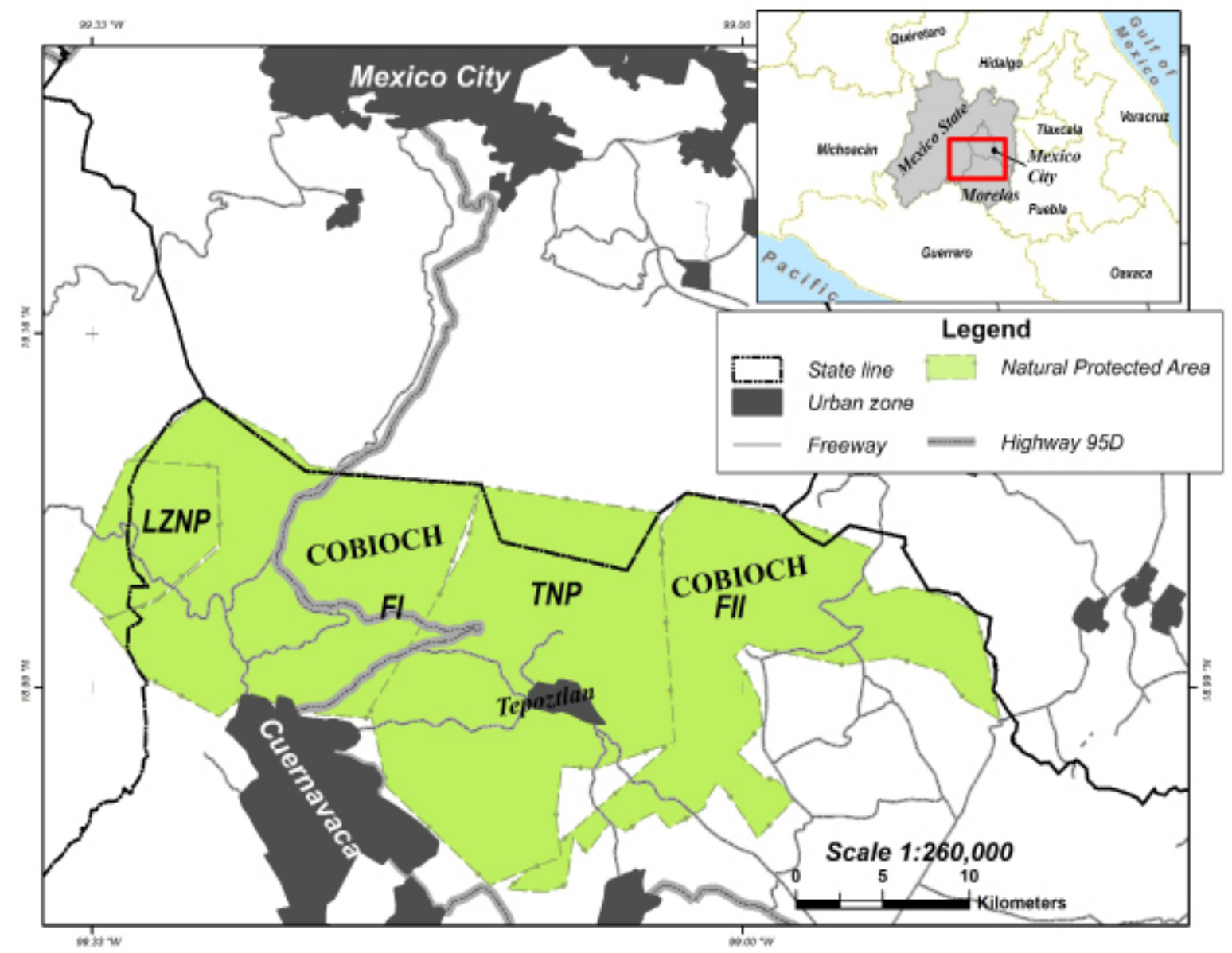

Figure 1. Location of the Corredor Biológico Chichinautzin Protected Area in Mexico. Lagunas de Zempoala National Park (LZNP),;Fraction I (FI) Fraction II (FII); El Tepozteco National Park (TNP). 
conducted the survey, both searching ahead and to each side of the transect while walking at a relatively constant speed of $0.5 \mathrm{~km} / \mathrm{h}$. All surveys were conducted between 7:00 and 9:00 h, which is the time of the day when the zacatuche rabbit is most active (Solorio-Damián 2013). The position of rabbits observed on the center line of the transect was recorded as a distance of zero, and for those observed to either side of the transect the distance $(\mathrm{m})$ was recorded perpendicularly from the rabbit to the center line (Buckland et al. 1993) using an electronic distance measuring tool, the Multi Measure Combo Pro (Sonin Inc.). The data were analyzed using the Distance 5.0 program (Thomas et al. 2010) to estimate rabbit density per hectare. To model the detection function of the perpendicular distances, data were pooled across all transects. Three models were considered for the detection function: half-normal, uniform and hazard rate. In each case, the need for cosine adjustment terms was assessed using likelihood ratio tests. In all analyses, $5 \%$ of the longest distances were shortened to avoid bias introduced by outlier distance sightings. The final model was chosen based on a combination of a low value for Akaike's information criterion (AIC) and low variance.

\section{Results}

The presence of the zacatuche rabbit was documented at 149 points within the northernmost part of the $\mathrm{COBIOCH}$. It was absent from 24 points with suitable habitat. The records include 48 sightings and 101 pellet counts. The estimated occupied area based on 49 historical records was 56.85 ha. Based on all our field records, the estimated area occupied by this species in the Protected Natural Area and the zone of influence was $166.43 \mathrm{~km}^{2}$ (Table 1). Most of this estimated area (98 ha) is located within the polygon of the $\mathrm{COBIOCH}$. Comparing this area with that estimated based on historical records (Figure 2), this one represents an increase of 109 ha of the occupied area previously known.

During the 12 months of the density survey, a total of 97 zacatuche rabbits were sighted along $96 \mathrm{~km}$ of transect. The analysis of this data using the Distance 5.0 software indicates that the half-normal +1 cosine model provided the best fit to our distance data according to the AIC and variance values (Table 2). This model estimates a density of 4.2 individuals/ha.

Table 1. Estimated area occupied by Romerolagus diazi $\left(\mathrm{km}^{2}\right)$ based on historical and recent records for the Corredor Biológico Chichinautzin (COBIOCH) Protected Natural Area.

\begin{tabular}{lcc}
\hline & \multicolumn{2}{c}{ Estimated area $\left(\mathbf{k m}^{2}\right)$} \\
& Historical records & Recent records \\
\hline Fractions I and II & 32.09 & 98.96 \\
El Tepozteco & 8.64 & 46.88 \\
Lagunas de Zempoala & 16.12 & 20.59 \\
Total area & 56.85 & 166.43 \\
\hline
\end{tabular}

\section{Discussion}

Our results represent an increase of the knowledge related to the range of the distribution for $R$. diazi into the $\mathrm{COBIOCH}$ and its influence zone. Most of the recent estimated area was not included in the distribution map proposed by Velázquez et al. (1996), which is the basis for the IUCN map (IUCN 2012). Clearly, our findings do not represent an expansion of the zacatuche rabbit in the Sierra de Chihinautzin, but reflects our intensive sampling. Before our field survey, there were only 49 historical records based on collecting data, literature and field surveys conducted in the study area (Appendixes 2 and 3 in Velázquez et al. 1996). 


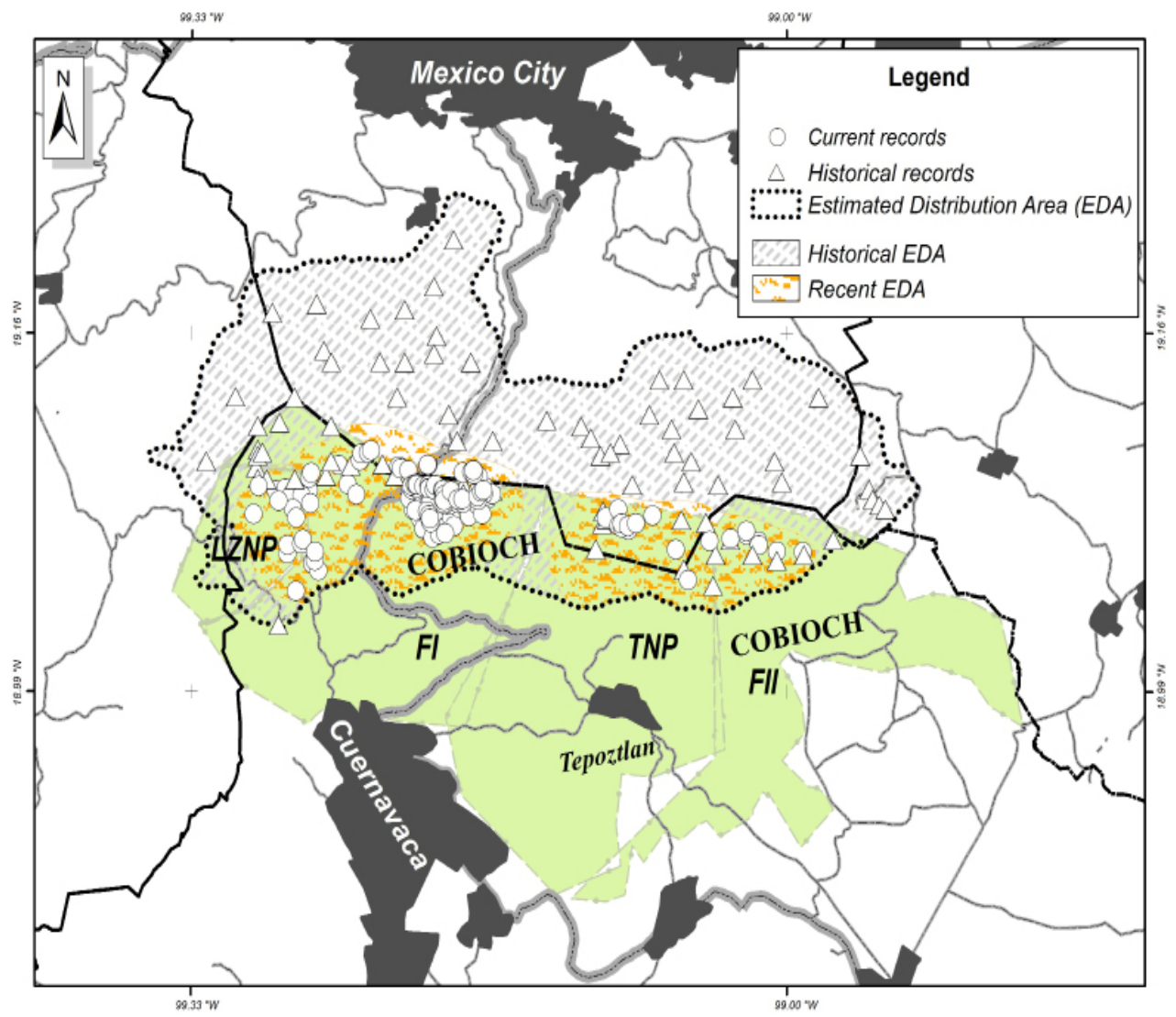

Figure 2. Distribution area of Romerolagus diazi within the Corredor Biológico Chichinautzin based on historical and recent records. LZNP, Lagunas de Zempoala National Park. FI, Fraction I. FII, Fraction II. TNP, EI Tepozteco National Park. Estimated areas are provided in Table 1.

Velázquez et al. (1996) based on those records, together with an analysis of climate, elevation and vegetation maps along the Trans-Mexican Volcanic Belt, recognized six peripheral areas (isolated from each other) for the zacatuche rabbit within the area inside the $\mathrm{COBIOCH}$. Our direct and indirect records point to a different scenario. First, the proximity of all the records indicates that the populations of the zacatuche rabbit might not be isolated from each other and that the rabbits are likely moving between landscapes. The only barrier to dispersal is the highway 95D (Mexico CityCuernavaca), built in 1952, that crosses the COBIOCH and has barred connectivity between populations on either side of it (Uriostegui-Velarde 2014). Second, Velázquez et al. (1996) recognized as core distribution areas of $R$. diazi those with suitable habitat where rabbits were sighted and traces (pellets) were found. The results presented here clearly meet these criteria, therefore indicating that the $\mathrm{COBIOCH}$ must be also considered a core area of the zacatuche rabbit. Added to that, our result regarding the estimated annual density also provides evidence that the $\mathrm{COBIOCH}$ is one of the most important habitats for zacatuche rabbit populations. Density estimated

Table 2. Annual density (D) of Romerolagus diazi estimated using Akaike's information criterion (AIC) and the percent coefficient of variation (\% CV) for each model.

\begin{tabular}{lccc}
\hline \multicolumn{1}{c}{ Model } & AIC & D & \% CV \\
\hline Half-normal + 1 cosine & 614.24 & 4.2 & 10.1 \\
Unifrom + 1 cosine & 675.68 & 7.7 & 14.7 \\
Hazard rate + 1 cosine & 668.13 & 8.1 & 12.5 \\
\hline
\end{tabular}


is higher than the only previous report of 1.2 rabbits/ha for the area of the Pelado Volcano using a similar methodology (Velázquez 1994).

These results make an important contribution to our knowledge of the distribution of $R$. diazi, and the evidence regarding its occurrence and density obtained during this study allow us to suggest that the $\mathrm{COBIOCH}$ provides a suitable habitat with conditions that are appropriate for $R$. diazi to establish and maintain populations with high abundances. It is therefore necessary to implement conservation actions that focus on habitat management and protection in order to avoid the habitat loss and fragmentation that result from grazing, crop cultivation and road construction.

\section{Acknowledgements}

We thank all students of the Facultad de Ciencias Biológicas, of the Universidad Autónoma del Estado de Morelos for helping with the field-work. This study was partially funded by the Comisión Nacional de Áreas Naturales Protegidas. A. RizoAguilar received a graduate studies scholarship from CONACYT (44564).

\section{Literature cited}

amcela (Asociación Mexicana Para la Conservación y Estudio de los Lagomorfos), F. J. RomeroMalpica, H. Rangel-Cordero, P. C. De Grammont, and A. D. Cuarón. 2008. Romerolagus diazi. The IUCN Red List of Threatened Species 2008: e.T19742A9008580. http://dx.doi. org/10.2305/IUCN.UK.2008.RLTS.T19742A9008580. Downloaded on 26 January 2016.

Buckland, S. T., D. R. Anderson, K. P. Burnham, and J. L. Laake. 1993. Distance Sampling: Estimating Abundance of Biological Populations. Chapman and Hall. London, United Kingdom.

Cabrera-García, L., J. A. Velázquez, and M. E. Escamilla. 2006. Identification of priority habitats for conservation of the Sierra Madre sparrow Xenospiza baileyi in Mexico. Oryx 40:211-217.

Fa, J. E., F. J. Romero, and J. López-Paniagua. 1992. Habitat use by parapatric rabbits in a Mexican high-altitude grassland system. Journal of Applied Ecology 29:357-370.

Harris, S., W. J. Cresswell, P. G. Forde, W. J. Trewhella, T. Woollard, and S. Wray. 1990. Home-range analysis using radio-tracking data-a review of problems and techniques particularly as applied to the study of mammals. Mammal Review 20:97-123.

Hoth, J., A. Velázquez, F. J. Romero, L. León, M. Aranda, and D. J. Bell. 1987. The volcano rabbit: a shrinking distribution and a threatened habitat. Oryx 21:85-91.

iUCN (International Union for Conservation of Nature). 2008. Romerolagus diazi. The IUCN Red List of Threatened Species. Version 2015-4

López-Forment, W., And F. A. Cervantes. 1979. Preliminary observations of the ecology of Romerolagus diazi in Mexico. World Lagomorph Conference. Guelph University. Guelph, Canada.

Rizo-Aguilar, A., J. A. Guerrero, M. G. Hidalgo-Mihart, and A. González-Romero. 2015. Relationship between the abundance of the endangered volcano rabbit Romerolagus diazi and vegetation structure in the Sierra Chichinautzin mountain range, Mexico. Oryx 49:360-365.

Semarnat (Secretaría de Medio Ambiente y Recursos Naturales). 2010. Norma Oficial Mexicana NOM-059-SEMARNAT-2010, Protección ambiental-Especies nativas de México de flora y fauna silvestres-Categorías de riesgo y especificaciones para su inclusión, exclusión o cambio-Lista de especies en riesgo. Diario Oficial de la 
Federación. Jueves 30 de diciembre de 2010. Segunda Sección, pp. 1-77.

Solorio-Damıán, M. 2013. Descripción de la actividad crepuscular del conejo zacatuche (Romerolagus diazi) en estado Silvestre en el Corredor Biológico Chichinautzin. Tesis de Licenciatura, Universidad Autónoma del Estado de Morelos. Cuernavaca, México.

Thomas, L., S. T. Buckland, E. Rexstad, J. L. Laake, S. Strindberg, S. Hedley, J. R. B. Bishop, T. A. Marques, AND K. P. Burnham. 2010. Distance software: design and analysis of distance sampling surveys for estimating population size. Journal of Applied Ecolology 47:514.

Uriostegui-Velarde, J. M. 2014. Conectividad de poblaciones de teporingo (Romerolagus diazi) en la Sierra del Chichinautzin. Tesis de Maestría, Universidad Autónoma del Estado de Morelos. Cuernavaca, México.

Velázquez, A. 1994. Distribution and population size of Romerolagus diazi on El Pelado Volcano, México. Journal of Mammalogy 75:743-749.

Velázquez, A., AND G. W. Heil. 1996. Habitat suitability study for the conservation of the volcano rabbit (Romerolagus diazi). Journal of Applied Ecology 33:543-554.

Velázquez, A., F. J. Romero, And L. León. 1996. Fragmentación del hábitat del conejo zacatuche. Pp. 73-86 en Ecología y conservación del conejo zacatuche (Romerolagus diazi) y su hábitat (Velázquez, A., F. J. Romero, y F. López-Paniagua, eds.). Universidad Nacional Autónoma de México y Fondo de Cultura Económica. Ciudad de México. México.

Velázquez, A., A. Larrazabal, and F. Romero. 2011. Del conocimiento específico a la conservación de todos los niveles de organización biológica. El caso del zacatuche y los paisajes que denotan su hábitat. Investigación Ambiental 3:59-62.

Worton, B. J. 1995. A convex hull-based estimator of home-range size. Biometrics 51:12061215.

Submited: March 16, 2016

Reviewed: April 4, 2016

Accepted: April 26, 2016

Associated editor: Consuelo Lorenzo 


\section{Appendix 1}

List of sampled points used to document both distribution and estimated occupied area of Romerolagus diazi within the $\mathrm{COBIOCH}$.

\begin{tabular}{|c|c|c|c|c|c|}
\hline & $\mathbf{x}$ & $\mathbf{Y}$ & & $\mathbf{x}$ & $\mathbf{Y}$ \\
\hline 1 & 481452.8630 & 2110266.7704 & 43 & 468505.3013 & 2110784.7857 \\
\hline 2 & 478781.8766 & 2108370.8834 & 44 & 469682.3159 & 2110006.8160 \\
\hline 3 & 479526.7436 & 2110152.6332 & 45 & 470225.3242 & 2107237.9499 \\
\hline 4 & 478861.7115 & 2110455.5028 & 46 & 470238.8004 & 2107681.3369 \\
\hline 5 & 477642.8210 & 2110156.6659 & 47 & 471039.5803 & 2107743.6436 \\
\hline 6 & 469528.2843 & 2110561.6963 & 48 & 471139.3437 & 2107960.9222 \\
\hline 7 & 470095.3161 & 2110646.8244 & 49 & 471508.5979 & 2111234.5920 \\
\hline 8 & 470445.3828 & 2110280.5183 & 50 & 471635.9637 & 2111470.7897 \\
\hline 9 & 478809.1557 & 2108203.6573 & 51 & 471849.9994 & 2106855.7496 \\
\hline 10 & 478830.1949 & 2108710.7495 & 52 & 471862.5065 & 2107320.1455 \\
\hline 11 & 478315.6355 & 2108526.9412 & 53 & 474542.1658 & 2112130.2452 \\
\hline 12 & 478158.4247 & 2109034.2433 & 54 & 474630.8961 & 2112506.5556 \\
\hline 13 & 478176.6789 & 2109642.7621 & 55 & 475018.2599 & 2112546.2835 \\
\hline 14 & 478229.9038 & 2110171.3304 & 56 & 475210.9037 & 2112666.7673 \\
\hline 15 & 479429.0815 & 2108525.6660 & 57 & 476852.6562 & 2111819.5911 \\
\hline 16 & 479453.0189 & 2109026.6088 & 58 & 476968.6579 & 2111699.5974 \\
\hline 17 & 477708.9807 & 2109529.6043 & 59 & 477487.0047 & 2110139.3884 \\
\hline 18 & 477532.1418 & 2110694.6526 & 60 & 477742.3155 & 2110814.5933 \\
\hline 19 & 477800.4594 & 2110267.1193 & 61 & 477865.0494 & 2109502.8715 \\
\hline 20 & 479503.2318 & 2109506.0086 & 62 & 478043.0510 & 2110618.2535 \\
\hline 21 & 478994.6300 & 2109395.9373 & 63 & 478257.6772 & 2109780.6970 \\
\hline 22 & 479970.4083 & 2109148.9770 & 64 & 478317.6782 & 2108533.7618 \\
\hline 23 & 480156.9184 & 2108666.2467 & 65 & 478590.6820 & 2111899.5868 \\
\hline 24 & 480935.3395 & 2109691.9517 & 66 & 478613.6823 & 2111876.5880 \\
\hline 25 & 481051.7239 & 2109200.0827 & 67 & 478635.6828 & 2109812.6953 \\
\hline 26 & 481991.2748 & 2110720.4900 & 68 & 478876.6865 & 2108059.7864 \\
\hline 27 & 482157.2441 & 2110111.7888 & 69 & 479007.7023 & 2110470.4311 \\
\hline 28 & 481613.3426 & 2109734.2912 & 70 & 479029.6886 & 2110830.6423 \\
\hline 29 & 474626.7103 & 2112185.9736 & 71 & 479262.6922 & 2108234.7773 \\
\hline 30 & 473285.1538 & 2111895.8928 & 72 & 479355.0674 & 2110590.4048 \\
\hline 31 & 473812.5856 & 2110887.0433 & 73 & 479590.6359 & 2110537.2276 \\
\hline 32 & 474329.0247 & 2110336.1694 & 74 & 479623.9575 & 2110290.3604 \\
\hline 33 & 471690.5902 & 2106706.9106 & 75 & 479627.6977 & 2108285.7746 \\
\hline 34 & 472060.6061 & 2106318.7862 & 76 & 479803.1711 & 2110296.3301 \\
\hline 35 & 470734.5925 & 2105250.0526 & 77 & 479907.4957 & 2109789.8364 \\
\hline 36 & 471624.5502 & 2111464.7116 & 78 & 480668.2739 & 2111484.5282 \\
\hline 37 & 471503.6491 & 2110564.6831 & 79 & 481182.3305 & 2111519.5964 \\
\hline 38 & 471056.1302 & 2110288.7695 & 80 & 481344.1039 & 2111424.8213 \\
\hline 39 & 471595.5202 & 2109881.6200 & 81 & 481642.5134 & 2111279.8588 \\
\hline 40 & 470552.3788 & 2109576.5260 & 82 & 481763.5223 & 2109955.8276 \\
\hline 41 & 470741.5907 & 2109112.1335 & 83 & 481840.9954 & 2109294.4620 \\
\hline
\end{tabular}


Rizo-Aguilar et al.

\begin{tabular}{|c|c|c|c|c|c|}
\hline & $x$ & $\mathbf{Y}$ & & $\mathbf{x}$ & $\mathbf{Y}$ \\
\hline 42 & 468210.2981 & 2109305.8626 & 84 & 482431.2751 & 2110350.7271 \\
\hline 85 & 489211.6459 & 2109112.8611 & 127 & 477925.6722 & 2110676.6504 \\
\hline 86 & 489946.5818 & 2109552.4782 & 128 & 478683.6835 & 2110448.6622 \\
\hline 87 & 489958.9280 & 2108696.6827 & 129 & 477981.6730 & 2110646.6520 \\
\hline 88 & 491000.6754 & 2108824.8860 & 130 & 478590.6820 & 2111899.5868 \\
\hline 89 & 491996.6992 & 2109227.8650 & 131 & 478717.6840 & 2109849.6934 \\
\hline 90 & 493376.7787 & 2107431.9383 & 132 & 477864.6714 & 2109502.7115 \\
\hline 91 & 494102.9175 & 2105834.8814 & 133 & 498337.9753 & 2107662.8062 \\
\hline 92 & 495393.7917 & 2107876.0152 & 134 & 477619.0386 & 2110806.2887 \\
\hline 93 & 496656.6384 & 2108011.2581 & 135 & 477807.7744 & 2110858.5430 \\
\hline 94 & 497617.1916 & 2108209.6678 & 136 & 477893.2357 & 2110876.4591 \\
\hline 95 & 498305.8069 & 2107862.9158 & 137 & 477949.4276 & 2110846.6226 \\
\hline 96 & 499402.8221 & 2107334.9533 & 138 & 478331.1302 & 2110758.0942 \\
\hline 97 & 500963.8503 & 2107296.9553 & 139 & 478543.6815 & 2109444.7144 \\
\hline 98 & 478591.6820 & 2111908.5864 & 140 & 478590.6820 & 2111899.5868 \\
\hline 99 & 477435.6649 & 2111628.6010 & 141 & 478613.1484 & 2110814.6882 \\
\hline 100 & 478694.6838 & 2109045.7352 & 142 & 478644.3449 & 2110663.8930 \\
\hline 101 & 479592.6970 & 2110086.6810 & 143 & 478651.4440 & 2110648.8798 \\
\hline 102 & 478676.6834 & 2110463.6614 & 144 & 478662.7023 & 2109246.1197 \\
\hline 103 & 479541.6962 & 2110249.6725 & 145 & 478714.5491 & 2109067.4050 \\
\hline 104 & 481348.7230 & 2111413.6119 & 146 & 478945.4344 & 2110604.2671 \\
\hline 105 & 479543.6963 & 2110378.6658 & 147 & 479032.0286 & 2110827.5345 \\
\hline 106 & 480008.7032 & 2110326.6685 & 148 & 479438.9327 & 2110545.8951 \\
\hline 107 & 480402.7091 & 2109869.6922 & 149 & 479477.7503 & 2110453.7519 \\
\hline 108 & 480681.7132 & 2109896.6908 & 150 & 479493.0675 & 2110066.1261 \\
\hline 109 & 480681.7132 & 2109896.6908 & 151 & 479494.0925 & 2110433.4790 \\
\hline 110 & 481936.7318 & 2110365.6663 & 152 & 479509.5507 & 2110450.2851 \\
\hline 111 & 481592.7267 & 2110038.6833 & 153 & 479509.5507 & 2110450.2851 \\
\hline 112 & 479526.6960 & 2110233.6733 & 154 & 479511.8728 & 2110579.1824 \\
\hline 113 & 490556.8599 & 2108475.7641 & 155 & 479511.8728 & 2110579.1824 \\
\hline 114 & 490169.8541 & 2108600.7576 & 156 & 479511.8728 & 2110579.1824 \\
\hline 115 & 478363.6787 & 2110557.6566 & 157 & 479560.5735 & 2110287.1816 \\
\hline 116 & 478645.6829 & 2110614.6536 & 158 & 479565.3606 & 2110016.3086 \\
\hline 117 & 479063.6891 & 2110627.6529 & 159 & 479976.7657 & 2110526.3381 \\
\hline 118 & 478746.6845 & 2108867.7444 & 160 & 480370.6836 & 2110069.6868 \\
\hline 119 & 479509.6958 & 2110253.6723 & 161 & 480650.0997 & 2110096.7964 \\
\hline 120 & 479597.6971 & 2109815.6951 & 162 & 481311.1034 & 2111624.8109 \\
\hline 121 & 479525.6960 & 2109865.6925 & 163 & 481311.1034 & 2111624.8109 \\
\hline 122 & 477839.6709 & 2110658.6514 & 164 & 481311.1034 & 2111624.8109 \\
\hline 123 & 477651.6681 & 2110605.6542 & 165 & 481315.8615 & 2111613.7235 \\
\hline 124 & 478977.6879 & 2110403.6645 & 166 & 481315.8615 & 2111613.7235 \\
\hline 125 & 479471.6952 & 2110345.6675 & 167 & 481560.3622 & 2110238.3500 \\
\hline 126 & 479387.6939 & 2110390.6652 & 168 & 481768.9663 & 2110476.9945 \\
\hline 169 & 481904.4453 & 2110565.8179 & & & \\
\hline
\end{tabular}


ZACATUCHE DISTRIBUTION AND DENSITY

\begin{tabular}{ccccc}
\hline & $\mathbf{X}$ & $\mathbf{Y}$ & $\mathbf{X}$ & $\mathbf{Y}$ \\
\hline 170 & 490137.5356 & 2108800.6563 & & \\
171 & 490525.0064 & 2108675.4957 & \\
172 & 491000.6754 & 2108824.8840 & \\
173 & 497585.1912 & 2108408.6525 & \\
\hline
\end{tabular}

